\title{
TEKNIK SUBSTRING WEIGHTING UNTUK KONVERSI MATA KULIAH
}

\author{
Yosi Malatta Madsu \\ Universitas Widyatama \\ Jl. Cikutra 204 A Bandung \\ yosi.malatta@widyatama.ac.id
}

\begin{abstract}
Abstrak
Konversi mata kuliah adalah suatu pekerjaan yang mungkin membutuhkan waktu lebih bila dilakukan secara manual. Pemindahan data transkrip menjadi data digital membutuhkan cara untuk memproses data tersebut lebih lanjut menjadi hasil konversi yang diinginkan. Salah satu cara untuk memproses data transkrip berbagai program studi dari berbagai perguruan tinggi menjadi hasil konversi yang diinginkan adalah dengan menggunakan Teknik Substring Weighting. Substring Weighting adalah implementasi text mining dari tiap-tiap nama mata kuliah asal yang dimanfaatkan dengan mekanisme pembobotan dan ranking untuk mencari hasil konversi terhadap mata kuliah tujuan. Hasil implementasi teknik ini dapat mempercepat proses administrasi konversi, $80 \%$ kasus konversi dapat dilakukan kurang dari 5 menit.
\end{abstract}

Kata kunci :

substring, weighting, mining, konversi mata kuliah.

\begin{abstract}
A manual academic transcript conversion will take a lot of time to be done. But when the digital process is involved, we need a method to process a whole academic transcript data to help to make good conversion results. Substring Weighting is a method to convert any academic transcript to specific academic transcript using text mining to every subject's name. Each substring may be weighted and sorted to match criterias of each destination subject. By these technique, at least $80 \%$ of conversion processes are done in less than 5 minutes.
\end{abstract}

Keywords :

substring, weighting, mining, transcript conversion.

\section{Pendahuluan}

Dalam program pindahan dan alih program antar program studi pada pendidikan tinggi harus melalui proses konversi mata kuliah untuk menyesuaikan kurikulum program studi asal dengan kurikulum program studi tujuan. Penyesuaian kurikulum antar program studi, dalam kaitannya dengan pemilihan mata kuliah-mata kuliah yang telah diambil oleh calon mahasiswa, harus melewati proses pemilihan mata kuliah dengan setiap mata kuliah tersebut harus bersesuaian dengan konteks dan materi pada mata kuliah tujuan. Sebagai contoh mata kuliah English Conversation, Academic English I, atau Bahasa Inggris 1 dapat dikonversi ke mata kuliah General English dengan pertimbangan bahwa mata kuliah tersebut memiliki kesamaan konteks dan rumpun pembahasan yang sama.

Proses konversi tersebut tidak serta-merta mudah dilakukan mengingat banyaknya ragam kurikulum dan komposisi mata kuliah dari program studi asal. Pada banyak kasus konversi, proporsi mata kuliah dasar, inti, dan pendukung akan sangat berbeda. Sebagai contoh beberapa kurikulum asal akan lebih banyak mata kuliah manajemen sedangkan kurikulum tujuan hanya memiliki sebuah mata kuliah manajemen. Hal tersebut akan menggugurkan mata kuliah yang tidak berkaitan dengan salah satu mata kuliah di kurikulum tujuan. Bila kurikulum asal dan kurikulum tujuan sangat jauh berbeda maka proses konversi akan membuat jumlah Satuan Kredit Semester (SKS) menjadi sangat sedikit. Oleh karena itu, proses konversi mata kuliah yang melihat kesesuaian secara materi lebih diperlebar secara lingkup maupun rumpunnya. Sebagai contoh, mata kuliah teknik dari kurikulum asal dapat dimasukkan ke mata kuliah teknik pada kurikulum tujuan dengan pertimbangan opsi terakhir atau beban konten teknik yang sepadan. Sedangkan mata kuliah non teknik tidak dapat 
dimasukkan ke dalam mata kuliah teknik.Jumlah SKS pada proses konversi tidak berubah pada saat sebuah mata kuliah diakui untuk dimasukkan menjadi mata kuliah tujuan, pun jika jumlah mata kuliah asal terlalu banyak maka akan dicukupkan pada mata kuliah tujuan, kemudian sisa SKS-nya dapat digunakan untuk mata kuliah tujuan lain secara parsial.

Proses konversi secara manual membutuhkan waktu yang tidak sedikit. Banyaknya calon mahasiswa pindahan dan alih program yang harus melalui tahap konversi menjadi pekerjaan ekstra pada urusan administrasi program studi. Padahal instansi dan program studi asal calon mahasiswa-mahasiswa bisa jadi sama atau memiliki kurikulum yang serupa. Sebuah metode konversi yang dapat digunakan dalam proses konversi mata kuliah asal ke mata kuliah tujuan secara otomatis menjadi sebuah kebutuhan. Karena proses konversi lebih banyak untuk mengenali sebuah mata kuliah untuk dijadikan calon pengisi mata kuliah tujuan melalui nama mata kuliah, maka diteliti sebuah teknik konversi berbasis pengolahan string yang didapat dari nama mata kuliah sebagai perhitungan sesuai atau tidaknya sebuah mata kuliah asal ke mata kuliah tujuan. Proses perhitungan dan analisa sinopsis string digunakan melalui pendekatan metode Text Mining (Olson 2008).

\section{SUBSTRING WeIGHT}

Beberapa mata kuliah asal dapat dimasukkan menjadi hasil konversi ke beberapa mata kuliah tujuan. Setiap calon mata kuliah asal yang dimasukkan sebagai hasil konversi ke mata kuliah tujuan dapat didefinisikan secara manual beberapa mata kuliah asal yang dinilai memiliki kesamaan konteks, rumpun, maupun beban mata kuliah. Pengetahuan terhadap definisi tersebut dapat dibuat daftar atau tabel sederhana untuk mendaftar mata kuliah asal yang terkait pada mata kuliah tujuan.

Tabel 1. Mata Kuliah Asal untuk Mata Kuliah General English

\begin{tabular}{ll}
\hline \hline No & Mata Kuliah Asal \\
\hline \hline 1 & English Conversation \\
2 & Academic English I \\
3 & Bahasa Inggris 1 \\
\hline \hline
\end{tabular}

Perlu diingat bahwa beberapa pilihan mata kuliah asal yang sesuai dengan mata kuliah tujuan dalam banyak kasus tidak serta merta tersedia, maka dari itu bila mata kuliah asal terkait tidak ada maka harus mencari calon-calon mata kuliah lain dengan berbagai pertimbangan kedekatan materinya.
Misalkan bila mata kuliah asal tersebut pada Tabel 1 tidak ada, maka ketika ada mata kuliah English for Business, mata kuliah tersebut dapat menjadi alternatif pilihan.

Substring daftar mata kuliah asal dapat menjadi pola atau kata kunci untuk mengenali sebuah mata kuliah sesuai atau tidak dengan mata kuliah tujuan (Rose 2010). Penggunaan substring yang berkaitan terhadap pemilihan mata kuliah asal menjadi kunci utama dalam tingkat kesesuaian mata kuliah. Substring tersebut digunakan sebagai metadata untuk memperbaiki penilaian secara efektif (Kudyba 2014). Misalkan dari Tabel 1 dapat diperoleh substring nama mata kuliah sebagai berikut: English, Conversation, Bahasa, Inggris, I, 1. Untuk substring 'Academic' dapat dihilangkan karena kurang sesuai dengan rumpun General English. Sedangkan substring 'I' harus dihilangkan karena hanya merupakan sebuah huruf, bila substring ini tetap dipakai maka pada setiap mata kuliah yang terdapat huruf 'I' akan dapat memiliki pengaruh pada saat perhitungan bobot nantinya.

Pada kebanyakan kasus konversi, nama mata kuliah asal dengan tujuan ada beberapa yang sama. Maka dari itu perlu didefinisikan substring yang didapat dari mata kuliah tujuan, atau bahkan dapat didefinisikan pula substring yang berupa nama lengkap mata kuliah tersebut.

Tabel 2. Substring untuk Mata Kuliah General English

\begin{tabular}{ll}
\hline \hline No & Substring \\
\hline \hline 1 & English \\
2 & Conversation \\
3 & Bahasa \\
4 & Inggris \\
5 & 1 \\
6 & General \\
7 & General English \\
\hline \hline
\end{tabular}

Perlu diperhatikan bahwa untuk mengetahui seluruh mata kuliah asal memiliki tingkat kedekatan yang tinggi dengan mata kuliah tujuan, ditambahkan nilai bobot pada masing-masing substring. Nilai bobot tersebut nantinya akan digunakan untuk menghitung kelayakan sebuah mata kuliah asal melalui mekanisme pengecekan pola tiap substring. Hasil perhitungan bobot tersebut dapat dianggap sebagai proses Pattern Summarization (Aggarwal 2015).

Penentuan besarnya nilai bobot sebuah substring dapat menggunakan pertimbangan tingkat frekuensi kemunculan maupun tingkat kedekatan dengan mata kuliah tujuan. Misalnya untuk substring 'General' 
dapat diberikan nilai bobot yang lebih kecil daripada 'English', sedangkan untuk substring 'General English' sendiri dapat diberikan nilai bobot yang lebih besar dari substring lainnya karena dinilai memiliki konten materi serumpun dengan mata kuliah tujuan, walaupun hanya dilihat dari nama mata kuliahnya. Penilaian bobot substring ' 1 ' lebih banyak sebagai alat bantu mendefinisikan tingkat kedekatan dengan bobot semester atau tahapan mata kuliah. Pada contoh, mata kuliah General English diberikan pada mata kuliah bertopik bahasa inggris di awal, maka substring ' 1 ' dapat digunakan untuk memberikan bobot lebih pada mata kuliah asal yang dimulai lebih dulu.

Tabel 3. Bobot Substring untuk Mata Kuliah General English

\begin{tabular}{llc}
\hline \hline No & Substring & Nilai Bobot \\
\hline \hline 1 & English & 700 \\
2 & Conversation & 600 \\
3 & Bahasa & 400 \\
4 & Inggris & 600 \\
5 & 1 & 100 \\
6 & General & 200 \\
7 & General English & 800 \\
\hline \hline
\end{tabular}

Untuk mendefinisikan sebuah mata kuliah adalah mata kuliah yang jauh kaitannya dengan mata kuliah tujuan dapat ditambahkan substring mata kuliah terkait untuk kemudian diberikan nilai bobot negatif. Nilai bobot negatif tersebut harus dipastikan akan membuat sebuah mata kuliah bernilai negatif pada saat dihitung secara keseluruhan. Sebagai contoh, untuk menghindari pemberian bobot jika tidak ada mata kuliah yang sesuai untuk General English tetapi ada kemungkinan mata kuliah asal terdapat 'Stadium General' atau 'Studium Generale' maka dapat ditambahkan substring dari mata kuliah asal tersebut.

Tabel 4. Penambahan Nilai Bobot Negatif

\begin{tabular}{llc}
\hline \hline No & Substring & Nilai Bobot \\
\hline \hline 1 & English & 700 \\
2 & Conversation & 600 \\
3 & Bahasa & 400 \\
4 & Inggris & 600 \\
5 & 1 & 100 \\
6 & General & 200 \\
7 & Stadium & -200 \\
8 & Studium & -200 \\
\hline
\end{tabular}

Pemberian nilai bobot pada mata kuliah tujuan sejatinya merupakan sebuah pendefinisian segala kemungkinan substring seluruh mata kuliah asal. Tetapi, karena dalam prosesnya, substring yang tidak dimasukkan pada tabel perhitungan dianggap bernilai nol, maka sebuah mata kuliah asal yang sama sekali tidak berkaitan dapat dilewati dan dianggap tidak memenuhi syarat penilaian dengan hanya tidak mendefinisikan substring tersebut

\section{RANKING}

Dalam proses akhir pemilihan mata kuliah asal hasil konversi, untuk tiap-tiap mata kuliah tujuan akan memiliki pemetaan nilai dari masing-masing mata kuliah asal. Seluruh matriks nilai hasil pemetaan mata kuliah asal dan mata kuliah tujuan tersebut kemudian dibuat tabel secara linear.

Kemudian, dari tabel matriks nilai tersebut dilakukan proses sorting menurun pada jumlah bobot. Langkah pengurutan tersebut dilakukan untuk mencari hasil konversi mata kuliah asal terbaik pada tiap-tiap kasus pembobotan terhadap mata kuliah tujuan. Proses pemilihan tersebut dimulai dari data hasil pengurutan teratas, dengan pengambilan mata kuliah tujuan yang memiliki ranking bobot tertinggi dapat diperoleh mata kuliah asal sebagai alternatif utama dalam penentuan hasil konversi. Bila ada mata kuliah asal sudah memiliki bobot lebih tinggi pada mata kuliah tujuan sebelumnya maka mata kuliah asal tersebut harus dilewati untuk kemudian dipilih mata kuliah asal dengan bobot tertinggi berikutnya.

Tabel 5. Tabel Matriks Nilai

\begin{tabular}{|c|c|c|}
\hline $\begin{array}{l}\text { Mata Kuliah } \\
\text { Asal }\end{array}$ & $\begin{array}{l}\text { Mata Kuliah } \\
\text { Tujuan }\end{array}$ & $\begin{array}{c}\text { Jumlah } \\
\text { Bobot }\end{array}$ \\
\hline $\begin{array}{l}\text { Pancasila dan } \\
\text { Kewarganegaraan }\end{array}$ & "General English & 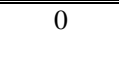 \\
\hline Etika Profesi & General English & 0 \\
\hline Bahasa Indonesia & General English & 400 \\
\hline Bahasa Inggris 1 & General English & 1100 \\
\hline Bahasa Inggris 2 & General English & 1000 \\
\hline Kalkulus & General English & 0 \\
\hline Pengantar Multimedia & General English & 0 \\
\hline Stadium Generale & General English & 0 \\
\hline Pancasila dan & Pendidikan Pancasila & 1000 \\
\hline Kewarganegaraan & & \\
\hline Etika Profesi & Pendidikan Pancasila & 100 \\
\hline Bahasa Indonesia & Pendidikan Pancasila & 0 \\
\hline Bahasa Inggris 1 & Pendidikan Pancasila & 0 \\
\hline Bahasa Inggris 2 & Pendidikan Pancasila & 0 \\
\hline Kalkulus & Pendidikan Pancasila & 0 \\
\hline Pengantar Multimedia & Pendidikan Pancasila & 0 \\
\hline Stadium Generale & Pendidikan Pancasila & 100 \\
\hline Pancasila dan & Kewarganegaraan & 300 \\
\hline Kewarganegaraan & & \\
\hline Etika Profesi & Kewarganegaraan & 400 \\
\hline Bahasa Indonesia & Kewarganegaraan & 0 \\
\hline Bahasa Inggris 1 & Kewarganegaraan & 0 \\
\hline Bahasa Inggris 2 & Kewarganegaraan & 0 \\
\hline Kalkulus & Kewarganegaraan & 0 \\
\hline Pengantar Multimedia & Kewarganegaraan & 0 \\
\hline Stadium Generale & Kewarganegaraan & 0 \\
\hline
\end{tabular}




\section{KONVERSI MATAKULIAH}

Proses konversi mata kuliah dari awal hingga akhir dengan Teknik Substring Weighting dapat dibagi menjadi beberapa langkah yang menentukan baik tidaknya hasil konversi.

\section{Entri data mata kuliah asal}

Dalam proses pemasukan data mata kuliah asal dari transkrip akademik masing-masing calon mahasiswa, setiap nama mata kuliah harus terketik dengan baik. Terjadinya salah ketik dapat mengakibatkan kesalahan pembobotan, kesalahan rangking, maupun kesalahan hasil konversi awal karena substring yang ada pada mata kuliah asal bisa jadi tidak dikenali pada proses pembobotan.

\section{Entri bobot mata kuliah tujuan}

Untuk setiap mata kuliah tujuan sejatinya membutuhkan pemetaan terhadap seluruh mata kuliah asal dari berbagai transkrip dan program studi asal. Setiap bobot diberikan melalui keterkaitan nama mata kuliah tujuan dengan banyak alternatif nama mata kuliah asal. Proses ini dapat dilakukan kembali untuk memberi perbaikan pada hasil konversi awal bila hasil konversi awal dinilai kurang sesuai dengan suatu kasus konversi pada transkrip program studi asal tertentu.

\section{Proses perhitungan bobot}

Proses perhitungan bobot dapat dilakukan secara otomatis untuk tiap-tiap mata kuliah pada tiap-tiap transkrip program studi asal. Proses yang terautomatisasi untuk seluruh kasus transkrip program studi sebaiknya dihindari karena dalam hal ini hasil konversi awal masih harus dievaluasi satu persatu.

4. Proses sorting/ranking

Proses sorting pada tabel seperti layaknya proses pengurutan pada basis data pada umumnya. Pengurutan dari nilai bobot yang paling tinggi ke paling rendah. Sebaiknya pada hasil konversi awal nilai bobot tersebut dimunculkan sebagai alat kontrol, karena hasil ranking dengan bobot nol pada mata kuliah tujuan dengan tidak adanya mata kuliah asal yang tidak cocok dapat terjadi.

5. Hasil konversi awal

Hasil konversi awal hanya merupakan sebuah alat penentu keputusan bahwa konversi tersebut nantinya dapat digunakan sebagai hasil konversi atau tidak. Proses pembobotan dan proses ranking sangat menentukan keluaran dari konversi, oleh sebab itu hasil konversi awal masih harus dilakukan evaluasi untuk setiap kasus bila terdapat anomali maupun pemilihan mata kuliah asal dengan bobot nol.
6. Kontrol dan evaluasi

Hasil konversi awal dapat digunakan sebagai alat kontrol kesesuaian terhadap hasil konversi yang diinginkan. Untuk setiap kasus konversi terhadap transkrip tertentu sebaiknya dilihat kembali apakah ada mata kuliah asal dengan bobot nol atau minimum. Hal itu dapat terjadi karena mata kuliah tujuan hampir tidak ada yang sesuai dengan salah satu mata kuliah dari transkrip asal. Bila ada yang kurang sesuai sebaiknya dilakukan evaluasi pembobotan kembali.

Pada kebanyakan kasus konversi nantinya akan ada konvergensi pembobotan untuk masing-masing kasus pada tiap-tiap program studi asal. Hal ini disebabkan rata-rata mata kuliah dari program studi perguruan tinggi yang sama hanya memiliki sedikit perbedaan nama mata kuliah, sehingga hasil dari beberapa kasus konversi dari transkrip mata kuliah dengan program studi perguruan tinggi yang sama akan terlihat konsisten dari hasil pembobotan dengan kasus yang sama. Jika hasil konversi awal dinilai sudah sesuai dengan yang diharapkan, maka dapat ditetapkan hasil konversi tersebut sebagai hasil akhir konversi untuk digunakan dalam proses akademik selanjutnya.

Hasil dari implementasi Teknik Substring Weighting pada proses administrasi konversi untuk sedikitnya 200 transkrip calon mahasiswa, $80 \%$ proses konversi dapat dikatakan sangat cepat dan dapat dilakukan kurang dari 5 menit. Aplikasi dengan pembobotan substring secara manual sebagai alat bantu konversi dibangun sebagai pendekatan machine learning yang dilakukan secara manual (Cox 2009). Alat bantu konversi tersebut dapat digunakan untuk menjadikan kasus-kasus konversi per mata kuliah yang sudah pernah dijumpai dapat dianggap sesuai dengan harapan pada saat hasil konversi awal keluar. $20 \%$ sisanya diproses lebih lama adalah karena adanya keterlibatan proses pembobotan ulang yang lebih banyak disebabkan ada beberapa mata kuliah dengan ketersesuaian minimum. Hal ini sering terjadi karena mata kuliah di kurikulum asal masih baru dan belum pernah disesuaikan dengan pembobotan sebelumnya. Dan beberapa di antaranya disebabkan karena adanya ketidaksesuaian kurikulum program studi awal dengan program studi tujuan.

\section{KESIMPULAN}

Konversi mata kuliah adalah suatu pekerjaan yang mungkin membutuhkan waktu lebih bila dilakukan secara manual. Penanganan tiap-tiap kasus konversi terhadap transkrip dari aneka ragam program 
studi perguruan tinggi asal bisa jadi merupakan sebuah proses administrasi yang berulang. Dengan cara memindahkan data transkrip menjadi data digital, dibutuhkan cara untuk memproses data tersebut menjadi hasil konversi yang diinginkan. Salah satunya adalah dengan menggunakan Teknik Substring Weighting, yaitu implementasi text mining dari tiaptiap nama mata kuliah asal yang dimanfaatkan sebagai dasar pembobotan untuk mencari hasil konversi terhadap mata kuliah tujuan.

Proses konversi secara terkomputerisasi dengan menggunakan Teknik Substring Weighting melalui tahapan sebagai berikut: entri data mata kuliah asal sebagai proses digitalisasi, entri bobot mata kuliah tujuan sebagai pendefinisian secara manual tentang keterkaitan mata kuliah asal dan mata kuliah tujuan, proses perhitungan bobot secara terkomputerisasi, proses sorting secara terkomputerisasi, dan keluaran hasil konversi sebagai alat bantu penentuan konversi akhir. Dengan menggunakan Teknik Substring Weighting sebagai alat bantu konversi dapat mempercepat proses konversi melalui pengolahan data transkrip hingga hasil konversi.

\section{REFERENSI}

Stuart Rose, Dave Engel, Nick Cramer and Wendy Cowley. 2010. "Automatic keyword extraction from individual documents". Text Mining: Applications and Theory. Wiley.

David L. Olson, Dursun Delen. 2008. Advanced Data Mining Techniques. Springer.

Stephan Kudyba. 2014. Big Data Mining and Analytics. CRC Press.

Chakrabarti, Cox, et. al. 2009. Data Mining Know It All. Morgan Kaufmann.

Charu C. Aggarwal. 2015. Data Mining The Textbook. Springer. 